\title{
Serotypes of Aggregatibacter actinomycetemcomitans in relation to periodontal status and geographic origin of individuals-a review of the literature
}

\author{
Jandenilson-Alves Brígido ${ }^{1}$, Virginia-Régia-Sousa da Silveira ${ }^{1}$, Rodrigo-Otávio Rego ${ }^{2}$, Nádia-Accioly-Pinto \\ Nogueira ${ }^{3}$
}

\footnotetext{
${ }^{1}$ Post-graduate Program in Dentistry, Faculty of Pharmacy, Dentistry and Nursing, Federal University of Ceará, Fortaleza, CE, Brazil

${ }^{2}$ Department of Dentistry, School of Dentistry at Sobral, Federal University of Ceará, Sobral, CE, Brazil

${ }^{3}$ Department of Clinical and Toxicological Analyses, Faculty of Pharmacy, Dentistry and Nursing, Federal University of Ceará, Fortaleza, CE, Brazil
}

Correspondence:

Rua Monsenhor Furtado s/n

Bairro Rodolfo Teófilo, Fortaleza, Ceará

CEP 60430-170, Brazil

jandenilson@hotmail.com

\author{
Brígido JA, da Silveira VRS, Rego RO, Nogueira NAP. Serotypes of Ag- \\ gregatibacter actinomycetemcomitans in relation to periodontal status \\ and geographic origin of individuals-a review of the literature. Med Oral \\ Patol Oral Cir Bucal. 2014 Mar 1;19 (2):e184-91. \\ http://www.medicinaoral.com/medoralfree01/v19i2/medoralv19i2p184.pdf

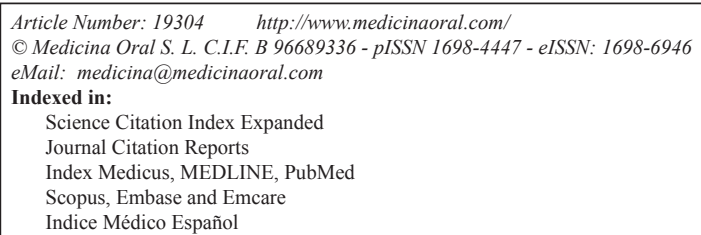

\begin{abstract}
Objectives: Several studies have focused on the relationship among serotype distribution, ethnical status and geographic populations, and periodontal conditions. Studies that have investigated the prevalence and the distribution of $A$. actinomycetemcomitans serotypes and the relation between the different serotypes of the bacterium and periodontal status were reviewed.

Material and Methods: A systematic literature search for publications regarding the distribution of A. actinomycetemcomitans serotypes in subgingival samples of periodontitis patients and periodontally healthy subjects by employing polymerase chain reaction (PCR) was conducted.

Results: From the 85 studies identified in the first analysis, only 12 met all inclusion and exclusion criteria. Clinical isolates from diverse geographic populations with different periodontal conditions were evaluated. Serotypes a, $\mathrm{b}$ and $\mathrm{c}$ were largely found, and serotype $\mathrm{c}$ was the most prevalent. They were isolated from various periodontal conditions, including aggressive periodontitis.

Conclusions: The available literature suggests that serotypes a, b, and c are globally dominant, serotypes $d$ and e are rare, and the prevalence of the most recently identified serotype $\mathrm{f}$ is still unknown. It is widely accepted that distribution patterns of $A$. actinomycetemcomitans vary among subjects of different ethnicity and geographic regions. The correlation of different serotypes with various periodontal conditions remains unclear.
\end{abstract}

Key words: Aggregatibacter actinomycetemcomitans, serotypes, periodontal disease, prevalence. 


\section{Introduction}

Periodontitis is a collective term for inflammatory conditions affecting supporting tissues of the teeth induced by microbial deposits (1). Progressive loss of tooth attachment in periodontis may eventually culminate in loss of affected teeth. As a consequence, periodontal disease is one of the most important concerns for dentists, patients and the public dental healthcare system. Epidemiological studies have shown that periodontal disease occurs predominantly in a slowly progressing form, chronic periodontitis, which in the majority of patients involves a limited number of teeth and rarely interferes with tooth function before adulthood (2). Periodontitis also occurs in a severe and rapidly progressing form, denoted aggressive periodontitis, which most often starts at an early age $(2,3)$.

Clinical and microbiological studies have identified only a few bacterial species associated with periodontal disease in adults (4). Aggregatibacter actinomycetemcomitans is a Gram-negative, nonmotile, facultative anaerobic cocobacillus bacterium that colonizes the human oral cavity, associated with the etiology of aggressive periodontitis (5-7), and can also be detected in the oral cavity of chronic periodontitis patients and periodontally healthy subjects $(8,9)$. This microorga-nism produces a variety of virulence factors, such as lipopolysaccharide, leukotoxin and cytolethal distending toxin (CDT) (10).

Development of techniques to detect the genetic variability of microorganisms has allowed for the observation of genetic differences in the leukotoxin promoter region between various $A$. actinomycetemcomitans strains, which are directly correlated with their leukotoxicity (11). Strains that are highly leukotoxic have a deletion of 530 base pairs in the leukotoxin promoter region, while those that are minimally leukotoxic present contain the complete leukotoxin promoter region. Thus, the highly leukotoxic strains (designated the JP2 clone) can produce 10 to 20 -fold more toxin than the others, providing them with the potential to interfere with the host's innate immune defense (12).

A. actinomycetemcomitans can be grouped into six serotypes (a-f) based on the polysaccharide antigen on the cell surface (13). Numerous studies have examined the relationship of A. actinomycetemcomitans serotype, ethnical status and geographic populations, and periodontal disease status, but with conflicting results (1417). Subjects are usually colonized by a single serotype, which can persist for life (18), and the frequency distribution of A. actinomycetemcomitans serotypes differs among various populations (19). There are no epidemiological studies on the distribution of A. actinomycetemcomitans serotypes, but the available literature suggests that serotypes $\mathrm{a}, \mathrm{b}$, and c occur much more frequently among oral isolates than serotypes $\mathrm{d}$, e, and $\mathrm{f}(13,20-22)$. Differences in serotype distribution have been shown among African, Asian, Europeans, and North and South American populations (21-25).

The different studies describe different microbiological identification techniques. Detection methods for $\mathrm{A}$. actinomycetemcomitans currently used include bacterial culture, DNA probe hybridization (20), specific antibody immunofluorescence (21), gene amplification via PCR methodology (22), including multiplex, nested multiplex and quantitative PCR. Each methodology varies with regard to detection time, the minimum number of cells that can be detected, and the ability to quantify the numbers of A. actinomycetemcomitans present in samples. PCR-based methods are not only suitable for the confirmation of strains, but have also been shown to have high sensitivity and specificity for the detection of A. actinomycetemcomitans from clinical samples of supragingival and subgingival plaque, and allow rapid detection of $A$. actinomycetemcomitans from clinical samples.

The objective of the present study was to review the studies that have investigated the prevalence and the distribution of $A$. actinomycetemcomitans serotypes in subgingival samples of periodontitis patients and periodontally healthy subjects by employing polymerase chain reaction (PCR) and to examine the possible association between periodontal conditions and serotypes.

\section{Material and methods}

Data sources and search strategy

The electronic database PubMed was searched systematically for studies published between January 2002 and December 2012. No language restrictions were applied. Both Mesh and Major terms were used in the search and Boolean operators (OR, AND) were used to combine the searches. The bibliographies of all potentially relevant studies and review articles were also searched. The search terms included "serotypes" AND "Aggregatibacter actinomycetemcomitans" OR "Actinobacillus actinomycetemcomitans" AND "periodontal disease" OR "periodontitis". The search was carried out twice by two different people. Study selection

Eligibility criteria applied to all studies retrieved by the search were established. Duplicate records or doublepublished studies and articles published before 2002 were excluded. No limitations were placed on the geographical location. Studies involving the distribution of $A$. actinomycetemcomitans serotypes in subgingival samples of periodontitis patients and periodontally healthy subjects by employing PCR were eligible for inclusion in this review. All abstracts were reviewed in order to identify any studies of interest. Two reviewers independently assessed the full-text articles for eligibility. Only studies which met all the eligibility criteria were finally included. Relevant data were abstracted from all studies meeting the eligibility criteria. The fol- 
lowing data were extracted from each study: (1) the first author and year of publication; (2) the country where the study was conducted; (3) searched serotypes; (4) Aim of study; (5) Principal findings and (6) possible association between periodontal conditions and serotypes.

\section{Results}

Eighty-five articles were identified, of which 66 were excluded based on their titles and abstracts. The full text of each of the 19 remaining papers was reviewed, and seven were excluded because they did not match the inclusion criteria for this review. The remaining 12 stud- ies were included in the review, nine cross-sectional studies and three longitudinal studies.

The study selection is presented in table 1 . The publication dates ranged from 2003 to 2012. The study sample sizes ranged from 49 to 486 individuals and the number of participants positive for A. actinomycetemcomitans ranged from 13 to 204 individuals. Participants' ages ranged from 4 to 82 years. Definition of periodontal disease varied greatly between the studies. Although majority of the studies defined periodontitis based on probing pocket depth (PPD) and/or clinical attachment level (CAL) measurements, their definitions varied in

Table 1. Description of the studies included in the review.

\begin{tabular}{|c|c|c|c|c|}
\hline Study & $\begin{array}{l}\text { Searched sero- } \\
\text { types / Type of } \\
\text { study }\end{array}$ & Aim of study & $\begin{array}{l}\text { Participants number(s), Aa- } \\
\text { positive individuals, Age }\end{array}$ & $\begin{array}{l}\text { Periodontal status/ Clinical } \\
\text { Parameters exam- } \\
\text { ined }\end{array}$ \\
\hline $\begin{array}{l}\text { Yoshida et } \\
\text { al., } 2003 \\
(26)\end{array}$ & $\begin{array}{l}\text { a-e Cross- } \\
\text { sectional study }\end{array}$ & $\begin{array}{l}\text { To examine the frequency of } \\
\text { mono- or poly-infection by Aa } \\
\text { serotypes and the relationship be- } \\
\text { tween the detection of Pg and the } \\
\text { distribution of Aa serotypes. }\end{array}$ & $\begin{array}{l}\text { Aa was detected in } 64(19.5 \%) \\
\text { of } 328 \text { subjects ( } 190 \text { males aged } \\
25-64 \text { years and } 138 \text { females aged } \\
22-59 \text { years). }\end{array}$ & $\begin{array}{l}\text { Minimal periodontal disease } \\
\text { or periodontally healthy/ } \\
\text { PPD. }\end{array}$ \\
\hline $\begin{array}{l}\text { Teixeira et } \\
\text { al. , } 2006 \\
(22)\end{array}$ & $\begin{array}{l}\text { a-f } \quad \text { Cross- } \\
\text { sectional study }\end{array}$ & $\begin{array}{l}\text { To evaluate the distribution of Aa } \\
\text { serotypes in subjects with and } \\
\text { without periodontitis and whether } \\
\text { there is an } \\
\text { association between serotype and } \\
\text { periodontal status. }\end{array}$ & $\begin{array}{l}\text { Aa strains isolated from subgin- } \\
\text { gival specimens of } 49 \text { Brazilian } \\
\text { subjects (from } 4 \text { to } 58 \text { years). }\end{array}$ & $\begin{array}{l}\text { Healthy periodontium; AgP; } \\
\text { CP (AAP, } 1999 \text { [3]) / PPD; } \\
\text { attachment loss; bleeding } \\
\text { or exudation on deep sites; } \\
\text { radiographic evidence of } \\
\text { alveolar bone loss. }\end{array}$ \\
\hline $\begin{array}{l}\text { Thiha et al., } \\
2007 \text { (27) }\end{array}$ & $\begin{array}{l}\text { a-e Cross- } \\
\text { sectional study }\end{array}$ & $\begin{array}{l}\text { To identify periodontopathic bac- } \\
\text { teria in diseased gingival tissue of } \\
\text { periodontitis patients. The distri- } \\
\text { bution of Aa serotypes } \\
\text { in tissue samples was also exam- } \\
\text { ined. }\end{array}$ & $\begin{array}{l}56 \text { subjects consisting of } 32 \mathrm{CP} \\
\text { (mean age } 55.13 \pm 7.46), 16 \mathrm{GAgP} \\
\text { (mean age } 35.07 \pm 8.23 \text { ) and } 8 \\
\text { LAgP (mean age } 31.29 \pm 5.56 \text { ). } \\
\text { Prevalence of Aa was higher in the } \\
\text { LAgP }(63 \%) \text { group. }\end{array}$ & $\begin{array}{l}\text { CP; GAgP; LAgP (AAP, } 1999 \\
\text { [3]) / PPD; CAL; BOP. }\end{array}$ \\
\hline $\begin{array}{l}\text { Fine et al., } \\
2007(6)\end{array}$ & $\begin{array}{l}\text { a-e Longitudinal } \\
\text { Cohort Study }\end{array}$ & $\begin{array}{l}\text { To study the prevalence of LAP, } \\
\text { the prevalence of Aa carriage, } \\
\text { the relationship of Aa carriage to } \\
\text { disease initiation. }\end{array}$ & $\begin{array}{l}\text { A cohort of } 96 \text { students was estab- } \\
\text { lished that included a test group } \\
\text { of } 38 \text { Aa-positive students and } 58 \\
\text { healthy Aa-negative controls (from } \\
11 \text { to } 17 \text { years - initial). }\end{array}$ & $\begin{array}{l}\text { Healthy; LAP / One } 4 \text { - or } \\
5 \text {-mm pocket; At least two } \\
5 \text {-mm pockets; At least one } \\
6 \text {-mm pocket with } 2 \mathrm{~mm} \text { of } \\
\text { attachment loss. }\end{array}$ \\
\hline $\begin{array}{l}\text { van der } \\
\text { Reijden et } \\
\text { al., } 2008 \\
(28)\end{array}$ & $\begin{array}{l}\text { a-f Longitudinal } \\
\text { Cohort Study }\end{array}$ & $\begin{array}{l}\text { To investigate the serotype distri- } \\
\text { bution and stability of Aa over an } \\
8 \text {-year period in untreated Indone- } \\
\text { sian subjects. }\end{array}$ & $\begin{array}{l}\text { From the total number of } 158 \\
\text { patients in } 1994,65 \text { ( } 41.1 \% \text { ) were } \\
\text { positive for Aa (mean age } 29.4 \\
\text { years). In } 2002,53 \text { ( } 49.5 \% \text { ) subjects } \\
\text { out of a total of } 107 \text { subjects were } \\
\text { Aa positive (mean age } 38.2 \text { years). }\end{array}$ & $\begin{array}{l}\text { Untreated periodontal disease } \\
\text { / PI; bleeding index; PPD; } \\
\text { CAL. }\end{array}$ \\
\hline $\begin{array}{l}\text { Hoglund } \\
\text { Aberg et } \\
\text { al., } 2009 \\
(29)\end{array}$ & $\begin{array}{l}\text { a-f Longitudinal } \\
\text { study }\end{array}$ & $\begin{array}{l}\text { To look for clinical signs of peri- } \\
\text { odontal disease in young adults } \\
\text { who exhibited } \\
\text { bone loss and detectable numbers } \\
\text { of Aa in their primary dentition. }\end{array}$ & $\begin{array}{l}13 \text { subjects who all exhibited bone } \\
\text { loss and were colonized by Aa } 16 \\
\text { years ago (aged } 7-9 \text { years). Aa was } \\
\text { recovered from six of these sub- } \\
\text { jects (aged } 23-25 \text { years). }\end{array}$ & $\begin{array}{l}\text { Detection of bone loss and Aa } \\
\text { in primary dentition / PPD; } \\
\text { BOP; ABL, alveolar bone } \\
\text { loss; PI. }\end{array}$ \\
\hline $\begin{array}{l}\text { Kim et al., } \\
2009(30)\end{array}$ & $\begin{array}{l}\text { a-f } \quad \text { Cross- } \\
\text { sectional study }\end{array}$ & $\begin{array}{l}\text { Compared serotypes of Aa in two } \\
\text { groups of periodontal patients with } \\
\text { different ethnic backgrounds. }\end{array}$ & $\begin{array}{l}194 \text { samples of subgingival plaque } \\
\text { from periodontal patients ( } 98 \\
\text { Koreans and } 96 \text { Germans) were } \\
\text { analyzed (ages ranged between } 27 \\
\text { and } 63 \text { years). } 45(23.2 \%) \text { tested } \\
\text { positive for Aa. }\end{array}$ & $\begin{array}{l}\text { Generalized severe periodon- } \\
\text { titis ( } \geq 30 \% \text { sites with CAL } \\
>4 \mathrm{~mm} \text {, more than two teeth } \\
\text { with }>50 \% \text { periodontal bone } \\
\text { loss in relation to the total } \\
\text { root length) / PI; GBI; PPD; } \\
\text { CAL. }\end{array}$ \\
\hline
\end{tabular}


Table 1. Continue.

\begin{tabular}{|c|c|c|c|c|}
\hline $\begin{array}{l}\text { Roman- } \\
\text { Torres et } \\
\text { al., } 2010 \\
\text { (31) }\end{array}$ & $\begin{array}{l}\text { a-f } \\
\text { Cross-sectional } \\
\text { study }\end{array}$ & $\begin{array}{l}\text { To elucidate the prevalence } \\
\text { of Aa and the distribution of Aa } \\
\text { serotypes in Brazilian subjects } \\
\text { with CP. }\end{array}$ & $\begin{array}{l}\text { Out of } 486 \text { subjects examined, Aa } \\
\text { was isolated in } 85(17.5 \%) \text { indi- } \\
\text { viduals (mean age } 33.41 \pm 9.76 \\
\text { years). }\end{array}$ & $\begin{array}{l}\mathrm{CP} \text { (slight }[1-2 \mathrm{~mm} \text { CAL], } \\
\text { moderate }[3-4 \mathrm{~mm} \text { CAL] or } \\
\text { severe [ }>5 \mathrm{~mm} \text { CAL]) / PPD; } \\
\text { CAL; GI; PI. }\end{array}$ \\
\hline $\begin{array}{l}\text { C. Chen et } \\
\text { al., } 2010 \\
(32)\end{array}$ & $\begin{array}{l}\text { a-f } \\
\text { Cross-sectional } \\
\text { study }\end{array}$ & $\begin{array}{l}\text { Examined the distribution pat- } \\
\text { tern of } \\
\text { Aa serotypes in the subgingival } \\
\text { plaque of subjects residing in the } \\
\text { United States. }\end{array}$ & $\begin{array}{l}\text { Aa was examined in } 256 \text { subgin- } \\
\text { gival plaque samples from } 161 \\
\text { subjects. A total of } 82 \text { distinct Aa } \\
\text { strains were identified (from } 11 \text { to } \\
32 \text { years). }\end{array}$ & $\begin{array}{l}\text { No periodontitis; LAP (with } \\
\text { at least two teeth, either } \\
\text { central incisors and/or first } \\
\text { molars, CAL } \geq 2 \mathrm{~mm} \text {, and } \\
\text { with fewer than other four } \\
\text { teeth with } \mathrm{AL} \text { ); GAgP (with } \\
\text { at least two teeth with } \geq 2 \\
\text { mm of AL in each of the four } \\
\text { quadrants) / PPD; Attachment } \\
\text { loss (AL). }\end{array}$ \\
\hline $\begin{array}{l}\text { Sakellari } \\
\text { et al., } 2011 \\
\text { (33) }\end{array}$ & $\begin{array}{l}\text { a-e } \\
\text { Cross-sectional } \\
\text { study }\end{array}$ & $\begin{array}{l}\text { To investigate the distribution of } \\
\text { Aa serotypes and the prevalence } \\
\text { of the JP2 clone in subgingival } \\
\text { samples of Greek subjects. }\end{array}$ & $\begin{array}{l}228 \text { subjects examined for Aa. } 40 \\
\text { subjects were positive for Aa (from } \\
29 \text { to } 82 \text { years). }\end{array}$ & $\begin{array}{l}\text { Non-periodontitis; Untreated } \\
\text { periodontitis Periodontitis } \\
\text { patients receiving supportive } \\
\text { treatment (CP or AgP - AAP, } \\
1999 \text { [3]) / PPD; BOP. }\end{array}$ \\
\hline $\begin{array}{l}\text { Bandhaya } \\
\text { et al., } 2012 \\
\text { (34) }\end{array}$ & $\begin{array}{l}\text { a-f } \\
\text { Cross-sectional } \\
\text { study }\end{array}$ & $\begin{array}{l}\text { To examine Aa serotypes, the } \\
\text { ltx promoter and the presence of } \\
\text { cdtABC genes in a group of Thai } \\
\text { adults. }\end{array}$ & $\begin{array}{l}\text { Subgingival plaque samples from } \\
453 \text { subjects were analysed for Aa. } \\
\text { Eighty six subjects (19\%) were } \\
\text { positive for Aa (aged } 38-59 \text { years). }\end{array}$ & $\begin{array}{l}\text { Mean PD; } \% \text { sites with PD } \geq \\
5 \mathrm{~mm} \text {; Mean CAL; } \% \text { sites } \\
\text { with CAL } \geq 4 \mathrm{~mm} / \mathrm{PPD} ; \\
\text { recession; CAL. }\end{array}$ \\
\hline $\begin{array}{l}\text { Cortelli et } \\
\text { al., } 2012 \\
\text { (35) }\end{array}$ & $\begin{array}{l}\text { a-f } \\
\text { Cross-sectional } \\
\text { study }\end{array}$ & $\begin{array}{l}\text { Investigated a large population of } \\
\text { individuals positive for Aa and } \\
\text { performed a two way analysis } \\
\text { assessing the relation between the } \\
\text { different serotypes of the bacte- } \\
\text { rium and periodontal conditions. }\end{array}$ & $\begin{array}{l}204 \text { individuals (mean age } 33.54 \pm \\
11.11 \text { ) positive for Aa. }\end{array}$ & $\begin{array}{l}\text { Non-periodontitis; } \mathrm{AgP} \text { (PPD } \\
>5 \mathrm{~mm} \text { and } \mathrm{CAL} \geq 4 \mathrm{~mm} \\
\text { at first molars and incisors); } \\
\text { Mild } \mathrm{CP}(\mathrm{PPD}>3 \mathrm{~mm} \text { in } \\
\text { at least four teeth and mean } \\
\text { periodontal CAL }>3 \mathrm{~mm}) ; \\
\text { Moderate/severe CP }(\mathrm{PPD}>3 \\
\mathrm{mm} \text { in at least four teeth and } \\
\text { mean periodontal CAL } \geq 5 \\
\mathrm{~mm}) / \text { PPD;CAL; GI; PI. }\end{array}$ \\
\hline
\end{tabular}

Aa, Aggregatibacter actinomycetemcomitans; Pg, Porphyromonas gingivalis; AgP, Aggressive Periodontitis; CP, chronic periodontitis; LAgP/ LAP, localized aggressive periodontitis; GAgP, generalized aggressive periodontitis; PPD, probing pocket depth; CAL, clinical attachment level; BOP, bleeding on probing; PI, plaque index; GI, gingival index; GBI, gingival bleeding index.

terms of the threshold for the extent and severity of these criteria. Various researches included a control group of periodontally healthy participants. Eight studies evaluated serotypes a-f and four studies examined serotypes a-e.

Clinical isolates from diverse geographic populations with different periodontal conditions were evaluated. The samples were obtained of the subjects from Japan, Brazil, United States, Indonesia, Sweden, Germany, Korea, Greece and Thailand.

Table 2 shows the prevalence and distribution of $A$. $a c$ tinomycetemcomitans serotypes and the relationship with periodontal status of the studies included in the review. Serotypes a, b and c were largely found, and serotype $\mathrm{c}$ was the most prevalent. These serotypes were isolated from various periodontal conditions, including aggressive periodontitis. Serotypes d, e, and f were either not detected or were relatively infrequent.

\section{Discussion}

There is convincing evidence of differences in serotype distribution related to geography and/or ethnic group. Available data indicate that the geographic distribution of serotypes is not uniform $(6,32,33)$. The distribution pattern of A. actinomycetemcomitans serotypes varies greatly depending on the periodontal status of the allocated population and the country where the study takes place $(22,26,27,32,33)$.

A. actinomycetemcomitans, an oral commensal which is also an opportunist pathogen has a distinct racial bias and a surprising range of potential virulence factors and virulence mechanisms. It is a pathogen not only in the periodontium but also in some non oral infections, possesses several virulence determinants which contribute to its ability to colonize the oral cavity, persist in the periodontal pocket, resist and evade host defenses, cause destruction to soft and hard tooth-supporting tis- 


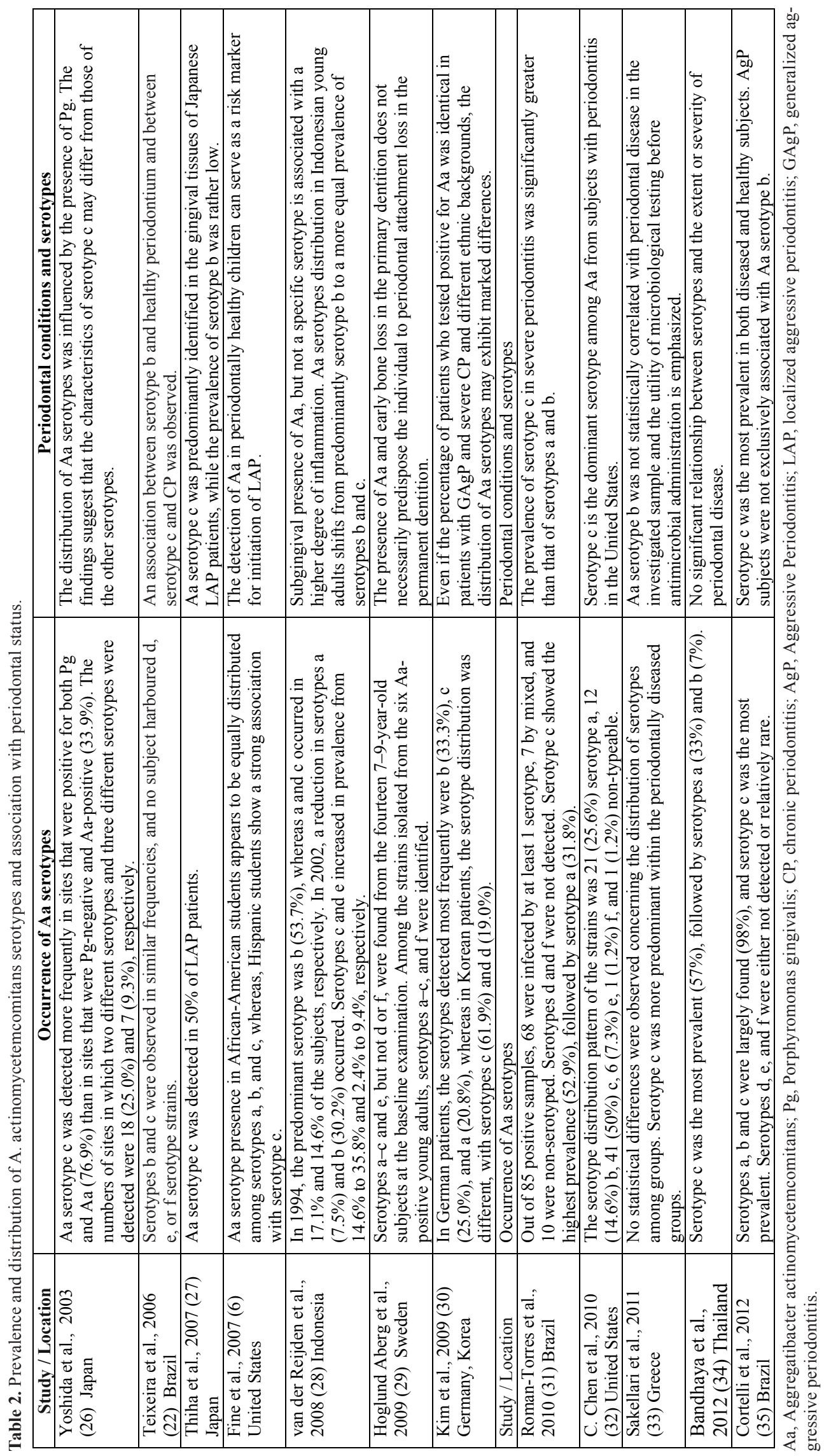


sues, and interfere with host tissue repair after infection. Several studies suggest that different $A$. actinomycetemcomitans serotypes are associated with periodontal health, periodontitis, and non-oral infections $(13,16,24)$, therefore the authors reviewed commensal with patho-

logical $A$. actinomycetemcomitans.

It has been suggested that patients are usually infected by only one serotype and colonization is stable over time $(28,30)$, however occasional individuals are colonized with two or three serotypes $(31,33,35)$. Most authors reported frequencies of multiple-serotype infection up to $20 \%(22,27,31)$. There have been a few exceptions, as in a Japanese study population where two or three serotypes of $A$. actinomycetemcomitans were detected in a percentage as high as $33 \%$ of the sites tested positive (26).

In general, the serotypes a-c occur much more frequently among oral isolates than serotypes $\mathrm{d}-\mathrm{f}$. The $A$. actinomycetemcomitans serotype presence in AfricanAmerican students appears to be equally distributed among serotypes a, b, and c, whereas, Hispanic students show a strong association with serotype c (6). Serotypes $\mathrm{a}, \mathrm{b}$ and $\mathrm{c}$ are equally dominant and collectively comprise $95 \%$ or more of all $A$. actinomycetemcomitans strains in Greece (33). In Brazilian subjects, serotypes a, b and c were largely found (98\%), and serotype c was the most prevalent. Serotypes d, e, and f were either not detected or relatively rare $(22,31,35)$. The distribution pattern of $A$. actinomycetemcomitans serotypes in the subgingival plaque of subjects residing in the United States showed that serotype $\mathrm{c}$ is the dominant serotype, followed by serotypes a and b, and serotypes $d$, e, and $\mathrm{f}$ were either not detected or relatively rare (32).

The studies showed that Asian populations were commonly colonized with $A$. actinomycetemcomitans serotype $\mathrm{c}$, but were occasionally infected with serotype b $(26,27,30,34)$. Two studies have examined the serotype distribution patterns of $A$. actinomycetemcomitans in a Japanese population. In both studies serotypes c was the dominant serotype, while serotype b was relatively rare (26,27). For 86 A. actinomycetemcomitans strains in Thai adults with varying degrees of periodontal disease severity the serotype c was the dominant serotype, followed by serotypes a (33\%) and b (7\%) (34), whereas in Korean patients, the serotype distribution was different, the serotypes detected most frequently were c $(61.9 \%)$ and $d(19.0 \%)(30)$. The differences between the results from these Asian populations shows that serotype distribution patterns may be affected by geographic variations, even between subjects of the same race/ethnicity. In contrast, serotype b was frequently observed in Caucasian populations (30). In German patients, the serotypes detected most frequently were b (33.3\%), c $(25.0 \%)$, and a $(20.8 \%)(30)$.
The serotype distribution pattern of $A$. actinomycetemcomitans within a local population may change over time, as was documented in Indonesian subjects with periodontitis between 1994 and 2002. In 1994, the predominant serotype was b (53.7\%), whereas a and c occurred in $17.1 \%$ and $14.6 \%$ of the subjects, respectively. In 2002 , a reduction in serotypes a $(7.5 \%)$ and b (30.2\%) occurred. Serotypes c and e increased in prevalence from $14.6 \%$ to $35.8 \%$ and $2.4 \%$ to $9.4 \%$, respectively (28).

Serotypes d-f were rarely detected in most populations worldwide $(32,33,35)$. However, a high prevalence of serotype e (19-47\%) was noted in Indonesian (28) and Japanese (26) individuals.

The application of molecular techniques has allowed a more detailed discrimination among different serotypes of $A$. actinomycetemcomitans and therefore the investigation of potential differences between populations of various origins as well as periodontal conditions. It has been suggested that some A. actinomycetemcomitans serotypes are more closely associated with periodontal disease than others.

In the United States, serotype c was the dominant serotype among $A$. actinomycetemcomitans from subjects with periodontitis (32), and in addition to the JP2 serotype $b$ phenotype, there are other strains that are equally associated with disease initiation (6). In Japanese patients, A. actinomycetemcomitans serotype c was predominantly identified in the gingival tissues of localized aggressive periodontitis patients, while the prevalence of serotype b was rather low (27), and the distribution of $A$. actinomycetemcomitans serotypes was influenced by the presence of Porphyromonas gingivalis (26).

In Indonesian subjects was observed that the mean increase in probing pocket depth between 1994 and 2002 was significantly greater in subjects culture positive in 2002 in comparison to subjects without detectable $A$. actinomycetemcomitans in 2002 (28). This confirms that subgingival presence of $A$. actinomycetemcomitans, but not a specific serotype is associated with a higher degree of inflammation (6).

In Brazil, an association between serotype $b$ and healthy periodontium and between serotype $\mathrm{c}$ and chronic periodontitis was observed (22), differing from other data, which associated serotype b strains with patients with aggressive periodontitis (35). Aggressive periodontitis subjects were not exclusively associated with $A$. actinomycetemcomitans serotype b $(31,35)$. In general, isolates from healthy subjects belonged to serotypes a or c (35). Serotype c was the most prevalent serotype among Brazilian A. actinomycetemcomitans, and they were isolated from various periodontal conditions, including aggressive periodontitis (35).

In a Greek population, $A$. actinomycetemcomitans was 
more prevalent in untreated periodontitis subjects, but no clear predominance of a specific $A$. actinomycetemcomitans serotype and absence of the JP2 clone were observed (33). In Sweden, the findings indicate that periodontitis affecting the primary dentition does not necessarily indicate the presence of periodontal attachment loss in the permanent dentition (29).

Population genetic studies of $A$. actinomycetemcomitans suggest that it is clonal, consisting of genetically distinct subpopulations that correlate with the known serotypes $(36,37)$. It has been proposed that the organism can be grouped into three major phylogenetic lineages comprising serotype b strains, serotype c strains, and serotype a, d, e and f strains (38). Associations between a single serotype b clonal lineage (JP2 clone) and the aggressive form of localized periodontitis in adolescents have been the focus of much investigation $(12,39)$. The JP2 clone shows a limited geographical and ethnic host range, predominating in subjects with an African lineage but absent from non-African populations from Northern Europe $(24,40)$.

The studies have varied widely in periodontal disease diagnosis and status, sampling protocols, study design and microbial detection methods and serotype analysis techniques, hindering comparison of the studies.

The elimination of $A$. actinomycetemcomitans from periodontal pockets has long been considered a target of periodontal therapy, and has been correlated with stable outcomes of treatment. If $A$. actinomycetemcomitans continues to be highly associated with disease development, its detection may be used as a risk marker for disease progression.

The findings from the studies reviewed indicate that different ethnic groups are preferentially colonized by different $A$. actinomycetemcomitans serotypes and the relationship between different A. actinomycetemcomitans serotypes and periodontal conditions remains unclear.

\section{References}

1. Pihlstrom BL, Michalowicz BS, Johnson NW. Periodontal diseases. Lancet. 2005;366:1809-20.

2. Armitage GC. Periodontal diagnoses and classification of periodontal diseases. Periodontol 2000. 2004;34:9-21.

3. Armitage GC. Development of a classification system for periodontal diseases and conditions. Ann Periodontol. 1999;4:1-6.

4. Haffajee AD, Socransky SS. Microbial etiological agents of destructive periodontal diseases. Periodontol 2000. 1994;5:78-111.

5. Henderson B, Wilson M, Sharp L, Ward JM. Actinobacillus actinomycetemcomitans. J Med Microbiol. 2002;51:1013-20.

6. Fine DH, Markowitz K, Furgang D, Fairlie K, Ferrandiz J, Nasri $\mathrm{C}$, et al. Aggregatibacter actinomycetemcomitans and its relationship to initiation of localized aggressive periodontitis: longitudinal cohort study of initially healthy adolescents. J Clin Microbiol. 2007;45:3859-69.

7. Faveri M, Figueiredo LC, Duarte PM, Mestnik MJ, Mayer MP, Feres M. Microbiological profile of untreated subjects with localized aggressive periodontitis. J Clin Periodontol. 2009;36:739-49.

8. Fives-Taylor PM, Meyer DH, Mintz KP, Brissette C. Virulence factors of Actinobacillus actinomycetemcomitans. Periodontol 2000. 1999;20:136-67.

9. Torrungruang K, Bandhaya P, Likittanasombat K, Grittayaphong C. Relationship between the presence of certain bacterial pathogens and periodontal status of urban Thai adults. J Periodontol. 2009;80:122-129.

10. Curtis MA, Slaney JM, Aduse-Opoku J. Critical pathways in microbial virulence. J Clin Periodontol. 2005;32:28-38.

11. Zambon JJ, Haraszthy VI. The laboratory diagnosis of periodontal infections. Periodontol 2000. 1995;7:69-82.

12. Brogan JM, Lally ET, Poulsen K, Kilian M, Demuth DR. Regulation of Actinobacillus actinomycetemcomitans leukotoxin expression: analysis of the promoter regions of leukotoxic and minimally leukotoxic strains. Infect Immun. 1994;62:501-8.

13. Kaplan JB, Perry MB, MacLean LL, Furgang D, Wilson ME, Fine DH. Structural and genetic analyses of $\mathrm{O}$ polysaccharide from Actinobacillus actinomycetemcomitans serotype f. Infect Immun. 2001;69:5375-84

14. Zambon JJ, Slots J, Genco RJ. Serology of oral Actinobacillus actinomycetemcomitans and serotype distribution in human periodontal disease. Infect Immun. 1983;41:19-27.

15. Saarela M, Asikainen S, Alaluusua S, Pyhala L, Lai CH, Jousimies-Somer H. Frequency and stability of mono- or poly-infection by Actinobacillus actinomycetemcomitans serotypes a, b, c, d or e. Oral Microbiol Immunol. 1992;7:277-9.

16. Asikainen S, Chen C, Slots J. Actinobacillus actinomycetemcomitans genotypes in relation to serotypes and periodontal status. Oral Microbiol Immunol. 1995;10:65-8.

17. Tsuzukibashi O, Takada K, Saito M, Kimura C, Yoshikawa T, Makimura M, et al. A novel selective medium for isolation of Aggregatibacter (Actinobacillus) actinomycetemcomitans. J Periodontal Res. 2008;43:544-8.

18. Asikainen S, Chen C. Oral ecology and person-to-person transmission of Actinobacillus actinomycetemcomitans and Porphyromonas gingivalis. Periodontol 2000. 1999;20:65-81.

19. Rylev M, Kilian M. Prevalence and distribution of principal periodontal pathogens worldwide. J Clin Periodontol. 2008;35:346-61.

20. Dahlén G, Widar F, Teanpaisan R, Papapanou PN, Baelum V, Fejerskov O. Actinobacillus actinomycetemcomitans in a rural adult population in southern Thailand. Oral Microbiol Immunol. 2002; $17: 137-42$.

21. Yang HW, Huang YF, Chan Y, Chou MY. Relationship of Actinobacillus actinomycetemcomitans serotypes to periodontal condition: prevalence and proportions in subgingival plaque. Eur J Oral Sci. 2005; 113:28-33.

22. Teixeira RE, Mendes EN, Roque de Carvalho MA, Nicoli JR, Farias LM, Magalhães PP. Actinobacillus actinomycetemcomitans serotype-specific genotypes and periodontal status in Brazilian subjects. Can J Microbiol. 2006;52:182-8.

23. Asikainen S, Lai CH, Alaluusua S, Slots J. Distribution of Actinobacillus actinomycetemcomitans serotypes in periodontal health and disease. Oral Microbiol Immunol. 1991;6:115-8.

24. Haubek D, Dirienzo JM, Tinoco EM, Westergaard J, López NJ, Chung CP, et al. Racial tropism of a highly toxic clone of Actinobacillus actinomycetemcomitans associated with juvenile periodontitis. J Clin Microbiol. 1997;35:3037-42.

25. Tinoco EM, Lyngstadaas SP, Preus HR, Gjermo P. Attachment loss and serum antibody levels against autologous and reference strains of Actinobacillus actinomycetemcomitans in untreated localized juvenile periodontitis patients. J Clin Periodontol. 1997;24:93744.

26. Yoshida Y, Suzuki N, Nakano Y, Shibuya K, Ogawa Y, Koga T. Distribution of Actinobacillus actinomycetemcomitans serotypes and Porphyromonas gingivalis in Japanese adults. Oral Microbiol Immunol. 2003;18:135-9.

27. Thiha K, Takeuchi Y, Umeda M, Huang Y, Ohnishi M, Ishikawa I. Identification of periodontopathic bacteria in gingival tissue of Japanese periodontitis patients. Oral Microbiol Immunol. 2007;22:201-7. 28. Van Der Reijden WA, Bosch-Tijhof CJ, Van Der Velden U, Van 
Winkelhoff AJ. Java project on periodontal diseases: serotype distribution of Aggregatibacter actinomycetemcomitans and serotype dynamics over an 8-year period. J Clin Periodontol. 2008;35:487-92. 29. Höglund Åberg C, Sjödin B, Lakio L, Pussinen PJ, Johansson A, Claesson R. Presence of Aggregatibacter actinomycetemcomitans in young individuals: a 16-year clinical and microbiological follow-up study. J Clin Periodontol. 2009;36:815-22.

30. Kim TS, Frank P, Eickholz P, Eick S, Kim CK. Serotypes of Aggregatibacter actinomycetemcomitans in patients with different ethnic backgrounds. J Periodontol. 2009;80:2020-27.

31. Roman-Torres CV, Aquino DR, Cortelli SC, Franco GC, Dos Santos JG, Corraini P, et al. Prevalence and distribution of serotype-specific genotypes of Aggregatibacter actinomycetemcomitans in chronic periodontitis Brazilian subjects. Arch Oral Biol. 2010;55:242-8.

32. Chen C, Wang T, Chen W. Occurrence of Aggregatibacter actinomycetemcomitans serotypes in subgingival plaque from United States subjects. Mol Oral Microbiol. 2010;25:207-14.

33. Sakellari DA, Katsikari A, Slini T, Ioannidis I, Konstantinidis A, Arsenakis M. Prevalence and distribution of Aggregatibacter actinomycetemcomitans serotypes and the JP2 clone in a Greek population. J Clin Periodontol. 2011;38:108-14.

34. Bandhaya P, Saraithong P, Likittanasombat K, Hengprasith B, Torrungruang K. Aggregatibacter actinomycetemcomitans serotypes, the JP2 clone and cytolethal distending toxin genes in a Thai population. J Clin Periodontol. 2012;39:519-25.

35. Cortelli JR, Aquino DR, Cortelli SC, Roman-Torres CVG, Franco GCN, Gomez RS, et al. Aggregatibacter actinomycetemcomitans serotypes infections and periodontal conditions: a two-way assessment. Eur J Clin Microbiol Infect Dis. 2012;31:1311-8.

36. Haubek D, Poulsen K, Asikainen S, Kilian M. Evidence for absence in Northern Europe of especially virulent clonal types of Actinobacillus actinomycetemcomitans. J Clin Microbiol. 1995;33:395401.

37. Poulsen K, Theilade E, Lally ET, Demuth DR, Kilian M. Population structure of Actinobacillus actinomycetemcomitans: a framework for studies of disease-associated properties. Microbiology. 1994;140:2049-60.

38. Kaplan JB, Schreiner HC, Furgang D, Fine DH. Population structure and genetic diversity of Actinobacillus actinomycetemcomitans strains isolated from localized juvenile periodontitis patients. J Clin Microbiol. 2002;40:1181-7.

39. Hayashida H, Poulsen K, Kilian M. Differences in iron acquisition from human haemoglobin among strains of Actinobacillus actinomycetemcomitans. Microbiology. 2002;148:3993-4001.

40. Haraszthy VI, Hariharan G, Tinoco EM, Cortelli JR, Lally ET, Davis E, et al. Evidence for the role of highly leukotoxic Actinobacillus actinomycetemcomitans in the pathogenesis of localized juvenile and other forms of early-onset periodontitis. J Periodontol. 2000;71:912-22.

\section{Conflict of interest}

The authors declare that they have no conflict of interests related to this study. 